\title{
Ultrasonography Education in General Surgery Resident Training Program and Evaluation of Level of Utrasonography Learning Curves of General Surgery Residents
}

\section{Genel Cerrahi Uzmanlık Eğitim Programında Ultrasonografi Eğitimi ve Cerrahi Asistanlarının Ultrasonografi Öğrenme Eğrilerinin Değerlendirilmesi}

\author{
Şener Balas ${ }^{1}$, Seray Akçalar ${ }^{2}$, Kerim Bora Yılmaz ${ }^{1}$, Melih Akıncı, Serhat Tokgoz ${ }^{1}$, Mehmet Saydam $^{1}$, Muzaffer \\ Akkoca $^{1}$, Onur Ergun ${ }^{2}$, Harun Karabacak ${ }^{1}$, İdil Güneș Tatar ${ }^{2}$, Baki Hekimoğlu ${ }^{2}$ \\ ${ }^{1}$ Sağlık Bilimleri Üniversitesi, Dışkapı Yıldırım Beyazıt Eğitim Ve Araştırma Hastanesi Genel Cerrahi Servisi, \\ Ankara, Türkiye \\ ${ }^{2}$ Sağlık Bilimleri Üniversitesi, Dışkapı Yıldırım Beyazıt Eğitim Ve Araştırma Hastanesi Radyoloji Servisi, \\ Ankara, Türkiye
}

\section{ÖZET}

GİRIŞ ve AMAÇ: Ultrasonografi (USG), visseral organları, çok yönlü kullanım olanakları ile gerçek zamanlı değerlendirilmesini sağlayan bir görüntüleme tekniğidir. Teşhis ve tedavi katkılarının yanı sıra, hasta takibinde çok önemlidir ve ayrıca intraoperatif kullanım için firsat verir. Bu çalışma, uzman eğitim programına dahil edilmesi gereken USG eğitimi modelini tartışmayı ve asistan doktorlara uygulanan sınavın etkinliğini değerlendirmeyi ve tiroid nodülü, safra taşı ve intraabdominal serbest sıvısı olan hastalarda öğrenme eğrisini değerlendirmeyi amaçlamaktadır.

YÖNTEM ve GEREÇLER: Etik kurul onayladıktan sonra, klinik eğitimin bir parçası olarak radyolog tarafından pratik, teorik ve USG' nin hasta başı kullanım eğitimi verildi.Teorik eğitimden sonra, radyoloğun himayesinde farklı kıdem yıllarından seçilen dört cerrahi asistan hasta başında pratik eğitim uygulandı. İki aşamalı bir sınav sistemi belirlendi ve cerrahi asistanlarının değerlendirilmeleri radyolog tarafından yapıldı. Sınav sonuçları istatistiksel olarak değerlendirildi ve istatistiksel anlamlılık düzeyi $\mathrm{p}<0,05$ olarak kabul edildi.

BULGULAR: Tiroid nodülleri için iki test sonucunun istatistiksel olarak anlamlı olduğu onaylandı (p: 0.0560). İntraabdominal serbest sıvının değerlendirilmesinin sonuçları, başka bir test yapılmasına gerek kalmadan başarılı olarak kabul edildi. Safra kesesi taşı için iki test sonucunun istatistiksel olarak hiçbir farkı olmadı̆̆ı onaylandı (p: 0.5316).

TARTIŞMA ve SONUÇ: USG eğitimi ülkemizde genel cerrahi eğitimi sırasında kısıtlı merkezin eğitiminin parçası olabilmektedir. USG eğitiminde kazanılan deneyimin ve genel cerrahi asistanlarının öğrenme eğrilerinin değerlendirilmesi ve literatüre sunulması faydalı olacaktır. Eğitim tekniğine dair tartışmalar başka merkezlerin bu eğitimi planlayabilmesi için yol gösterici olacaktır.

Anahtar Kelimeler: Ultrasonografi, Asistan Eğitimi, Öğrenme Eğrisi, Yatakbaşı Ultrasonografi

\begin{abstract}
INTRODUCTION: Ultrasonography (USG) is an imaging technique that enables real-time evaluation of visceral organs via versatile utilization possibilities. Besides diagnosis and treatment contributions, it is crucial in patient follow-up and it also gives an opportunity of intraoperative usage. This study aims to discuss a model of USG training which should be included in the specialist training program and to evaluate the effectiveness of the examination applied to resident doctors and to evaluate the learning curve on patients with thyroid nodule, bile stone stone and intraabdominal free fluid.

METHODS: After the ethics committee approving, practical, theoretical training and per-patient usage of USG was given by the radiologist as a part of the clinical training. After the training, four surgical assistants selected from different years of residenties were practiced on a patient basis, under possesion of the radiologist. A twostage examination system was determined and the evaluations of the surgical residents were made by the
\end{abstract}


radiologist and the deficiencies were determined specially for the residents. Statistical significance was considered as the level of $\mathrm{p}<0.05$.

RESULTS: The two test results for thyroid nodules were approved to have made significant progress (p: 0.0560). The results of evaluating the intraabdominal free fluid were regarded as successful without any further testing. The two test results for for gallbladder stone were approved to have no statistically difference (p: $0.5316)$.

DISCUSSION AND CONCLUSION: USG training might be a part of general surgery resident training program only a few center in our country. The experience gained in USG training and the evaluation of the learning curves of general surgery residents and the presentation of the literature to them will be helpful. Discussions on training techniques will guide other centers to plan this training.

Keywords: USG, Resident Program Learning Curve, Chairside USG

\section{INTRODUCTION}

Ultrasonography (USG) is a commonly used imaging technique in clinical practice that allows real-time evaluation of visceral organs with versatile usage possibilities. The fact that it can be applied effectively, easily, and harmlessly, currently it is regarded as complementary to the physical examination (13). USG applications in trauma patients include many invasive procedures and Focused Abdominal Sonography for Trauma (FAST) applications are included in contemporary training programs and trauma guidelines (4). "Emergency USG" / "Chairside USG" applied by clinicians; is a more limited protocol than comprehensive evaluation of the radiology and only seeks to reply to the targeted questions (4, 5). Emergency USG; is an adjunctive test that can be applied to the bedside when needed in medical conditions and allows imaging of the disease when the treatment is decided. Besides diagnosis and treatment contributions, it is important in patient follow-up and there is also a chance of intraoperative use.

To date, sonographic applications for trauma have been using effectively by clinicians $(6,7)$. To ensure the reliability of the results of clinician practices, the learning curves must be assessed and the training techniques must be standardized $(8,9)$. In order to use USG for desicion of treatment, primarily it is crucial to be obtained a standardized training and make certain evaluations under possesion of the supervisor. To enhance the application competence and interpretation ability, USG practitioner must first learn anatomy and evaluate pathological events based on this training (10). Theoretical training on the characteristics of the USG device, evaluation of specific organ anatomy, organ pathologies and practical training under possesion of the supervisor is so essential for learning and application effectiveness $(1,11)$.

The aim of this study is to discuss USG training program which should be included in the General Surgery Resident Training Program and to evaluate the effectiveness of the technique performed by assistant doctors and to evaluate the learning curve on patients with thyroid nodule, bile stone stones and intraabdominal free fluid.

\section{MATERIAL and METHOD}

This study approving by Local Ethics Committee was conducted in the Ankara Dışkap1 Training and Research Hospital General Surgery Clinic. The theoretical and practical usage of USG was given to all clinical members by an experienced radiology specialist. This training aiming to whole surgical residents include basic principles of ultrasound, technical features of the device, organ anatomy, imaging in USG, determination of free abdominal fluid, evaluation of thyroid and its nodules, evaluation of gallbladder and stone findings and interpretation of images. All of the patients included the study approved the consent forms. Chairside practice and evaluation of the hospitalized patients in preoperative period was performed with under possesion of a supervisor. Four surgical assistants selected for the current study from different seniority of residenties after theoretical and practical training. In order to increase the effectiveness of these theoretical and practical trainings, general surgeons were required to participate in radiology applications as an observer during shifts and clinical working hours. A practical 
and theoretical examination about biliary diseases was carried out in terms of stone size and number, wall thickness and free fluid in the pericholecystic, and intraabdominal area. In addition residents were required to explain the nodule size and number, spesifications of nodule sonography for the practical evaluating of the thyroid diseases. A two-staged examination (pre and post education) system was established and the results of the surgeons' evaluation of the efficacy and results of the surgical procedure were made by radiologists and their deficiencies were determined. The development of the residents in the usage of the technique were tried to follow, and education was adjusted and interpreted in this direction via these two exams. Statistical analyzes applied for the study were done using STATA 10.0 program, and statistical significance level was approved as $(\mathrm{p}<0,05)$.

\section{RESULTS}

The median of first exam's results were $18,8(12,0-33,8)$, and 20(13-36) respectively and median of exam's results were $17,5(11,3-$ $22,3)$ and $18(12,3-21,8)$ respectively, in the two stage examination for thyroid nodules. In both tests, the expert values were considered as referenced criterion and the two test results of the assistants were compared with the MannWhitney U test (p: 0.0560) and the assistants were considered to have made significant progress (Table 1).

The results of evaluating the intraabdominal free fluid were regarded as successful without any further testing. The median of first exam's results were $8(7-10,4)$, and $8(7,3-11,0)$ respectively and median of the second exam's results were $11,0(8,5-12,0)$, and $11,0(8,5-12,0)$ respectively, in the two stage examination for gallbladder stone. In both tests, the expert values were considered as referenced criterion again and the two test results of the assistants were compared with the Mann-Whitney U test (p:0.5316) and there was no statistically difference between the two exams of the assistants (Table 1). For this reason, it was thought that the training for bile gallbladder stone should be taken into consideration.

\section{DISCUSSION}

USG applications have become popular not only in general surgery, but also in the other surgical branches such as obstetrics and urology, because of auxiliary usage such as being suitable for interventional procedures, and intraoperative use. From different clinical branches, practitioners have been shown to use USG featly for certain limited assessments according to a wide range of studies $(12,13)$. USG application have been included in trauma guidelines for determining the need for surgery, detecting hemopericardium, hemoperitoneum, and hemothorax with thoracoabdominal trauma patients (14). Replacing chairside USG instead of direct radiogram implements to detect pleural effusion and pneumothorax in trauma patients more effectively, an also provides both the protection of the patient's unnecessary radiation and the waste of clinician's time (1416). It can also facilitate the evaluation of patients with multiple bone fractures who are difficult to follow and need to be immobilized. Furthermore, it is so valuable to protect the pregnants from the ionizing radiation (17). The detection of soft tissue abscesses and their drainage, the detection of foreign bodies in the soft tissue, and the verification of incompetent hernias can be counted the other fields of usage $(14,18)$. Percutaneous drainage of intraabdominal fluids, percutaneous cholecystostomy, and differential diagnosis of acute pain causes can be performed via USG guidance. Fascia defects and wound dishences can be diagnosed early on with USG (14). USG guidance in all central catheter applications is recommended in guidelines because it increases success rate, reduces complication rates and costs (19-21). Many procedures such as endotracheal intubation, breast and various parenchymal organs, biopsies, thoracentesis, paracentesis, nerve blocks, endorectal and endoscopic applications can be performed reliably and effectively under USG guidance (22-24).

Ongoing debates and discussions about the type and duration of the theoretical and practical education, the number of patients required to complete the learning curve, the learning of invasive procedures with guidance of USG and the outcome of the training are 
present in the literature $(12,25,26)$. The core residency programme covers main aspects for all modalities and organ systems and should be based on the learning curves of the techniques. Hence, the learning curve of radiology techniques during medical education, radiology and clinical residency and practice have gained importance in the medical literature in the recent years (27).

USG training can be a part of the education of General Surgery Redident Program in only limited centers in our country. In surgical branches such as obstetrics, urology and cardiovascular departments, USG training is taught effectively in clinical practice and provides surgeons with increased diagnostic and therapeutic efficacy. USG training should be standardized in terms of trauma and emergency applications, breast-endocrine surgery, hepatobiliary evaluation and invasive procedures during General Surgery Resident program

Unfortunately, there are some important limitations about this study due to being preliminary study, though being one of the few studies available regarding the evaluation of USG training in general surgery resident program in Turkey. In our clinic, the absence of trainees who can train trainees about USG practices in the General Surgery teaching staff has been compulsory to conduct the training in conjunction with the Radiology department and has prevented this imaging method from being standardized in general surgical clinical applications and becoming internalized into clinical practice. The interests of the general surgery residents from four different seniorities differed from each other. Differences in the participation of assistants to procedures outside of their compulsory practices after standard theoretical and patientbased practical training given to the whole clinic within the working set have hampered the standardization of pre-examination practices.

\section{CONCLUSION}

USG training can be a part of the education of General Surgery Redident Program in only limited centers in our country. The learning curve of USG technique can be completed quickly as it moves towards being a necessity with the clinical practice being part of the physical examination. Training of trainers is also so important and must be a part of general surgery and assistant training.

\section{Conflict of interest: None}

Table 1: Analysis of The Exam Results

Tyhroid Diseases

Billiar Diseases

\begin{tabular}{|c|c|c|c|c|c|}
\hline \multicolumn{3}{|c|}{ Phase Median } & \multicolumn{3}{|c|}{ Phase Median } \\
\hline Pre & $\begin{array}{c}18,8(12,0-33,8) \\
20(13-36)\end{array}$ & & Pre & $\begin{array}{l}8(7-10,4) \\
8(7,3-11,0)\end{array}$ & \\
\hline Post & $\begin{array}{c}17,5(11,3-22,3) \\
18(12,3-21,8)\end{array}$ & *p: 0.0560 & Post & $\begin{array}{l}11,0(8,5-12,0) \\
11,0(8,5-12,0)\end{array}$ & *p:0.5316 \\
\hline
\end{tabular}

*Mann-Whitney U test 


\section{REFERENCES}

1- Mircea PA, Badea R, Fodor D, Buzoianu AD. Using ultrasonography as a teaching support tool in undergraduate medical education-time to reach a decision. Med Ultrason. 2012; 14: 211-6.

2- Arienti V, Di Giulio R, Cogliati C, Accogli E, Aluigi L, Corazza GR, et al. Bedside ultrasonography (US), Echoscopy and US point of care as a new kind of stethoscopefor Internal Medicine Departments: the training program of the Italian Internal Medicine Society (SIMI). Intern Emerg Med. 2014; 9:805-14.

3- Coşkun F, Akıncı E, Ceyhan MA, Sahin Kavaklı H. Our new stethoscope in the emergency department: handheld ultrasound. Ulus Travma Acil Cerrahi Derg. 2011; 17: 488-92.

4- Boulanger BR, Kearney PA, Brenneman FD, Tsuei B, Ochoa J. Utilization of FAST (focused assessment with sonography for trauma) in 1999: results of a survey of North American trauma centers. Am Surg. 2000; 66: 1049-55.

5- Gaspari RJ, Dickman E, Blehar D. Learning curve of bedside ultrasound of the gallbladder. J Emerg Med. 2009; 37: 51-6.

6- Schlager D, Lazzareschi G, Whitten D, Sanders AB. A prospective study of ultrasonography in the ED by emergency physicians. Am J Emerg Med. 1994; 12: 185-9.

7- Boulanger BR, McLellan BA, Brenneman FD, Wherrett L, Rizoli SB, Culhane J, Hamilton P. Emergent abdominal sonography as a screening test in a new diagnostic algorithm for blunt trauma. $\mathbf{J}$ Trauma. 1996; 40: 867-74.

8- Kern SJ, Smith RS, Fry WR, Helmer SD, Reed JA, Chang FC. Sonographic examination of abdominal trauma by senior surgical residents. Am Surg. 1997; 63: 669-74.

9- Buzzas GR, Kern SJ, Smith RS, Harrison PB, Helmer SD, Reed JA. A comparison of sonographic examinations for trauma performed by surgeons and radiologists. J Trauma. 1998; 44: 6046.

10- García de Casasola Sánchez G, Torres Macho J, Casas Rojo JM, Cubo Romano P, Antón Santos JM, Villena Garrido V, Diez Lobato R; Working Group SEMI Clinical.Abdominal ultrasound and medical education.Rev Clin Esp (Barc). 2014; 214 : 131-6.

11- Garcia-Casasola G, Sánchez F, Luordo D, Zapata DF, Frías MC, Garrido VV, Martínez JV, de la Sotilla AF, Rojo JM, Macho JT.Basic Abdominal Point-of-Care Ultrasound Training in the Undergraduate: Students as Mentors.J Ultrasound Med. 2016; 35: 2483-2489.

12- Smith RS, Kern SJ, Fry WR, Helmer SD. Institutional learning curve of surgeon-performed trauma ultrasound. Arch Surg 1998; 133: 530-5.

13- Hasani SA, Fathi M, Daadpey M, Zare MA, Tavakoli N, Abbasi S. Accuracy of bedside emergency physician performed ultrasound in diagnosing different causes of acute abdominal pain: a prospective study. Clin Imaging. 2015; 39: 476-9.

14- Rozycki GS. Surgeon-performed ultrasound: its use in clinical practice. Ann Surg. 1998; 228: 16-28.

15- Dente CJ, Ustin J, Feliciano DV, Rozycki GS, Wyrzykowski AD, Nicholas JM, Salomone JP, Ingram WL. The accuracy of thoracic ultrasound for detection of pneumothorax is not sustained over time: a preliminary study. J Trauma. 2007; 62: 1384-9.

16- Rozycki GS, Ochsner MG, Feliciano DV, Thomas B, Boulanger BR, Davis FE, Falcone RE, Schmidt JA. Early detection of hemoperitoneum by ultrasound examination of the right upper quadrant: a multicenter study. J Trauma. 1998;45:878-83.

17- Ma OJ, Mateer JR, DeBehnke DJ. Use of ultrasonography for the evaluation of pregnant trauma patients. J Trauma. 1996; 40: 665-8.

18- Yokoyama T, Munakata Y, Ogiwara M, Kamijima T, Kitamura H, Kawasaki S. Preoperative diagnosis of strangulated obturator hernia using ultrasonography. Am J Surg. 1997; 174: 76-8.

19- Dodge KL, Lynch CA, Moore CL, Biroscak BJ, Evans LV. Use of ultrasound guidance improves central venous catheter insertion success rates among junior residents. $\mathrm{J}$ Ultrasound Med. 2012; 31: 1519-26.

20- Rupp SM, Apfelbaum JL, Blitt C, Caplan RA, Connis RT, Domino KB, Fleisher LA, Grant S, Mark JB, Morray JP, Nickinovich DG, Tung A. Practice guidelines for central venous access: a report by the American Society of Anesthesiologists Task Force on Central Venous Access. Anesthesiology. 2012; 116: 539-73.

21- Lamperti M, Bodenham AR, Pittiruti M, Blaivas M, Augoustides JG, Elbarbary M, Pirotte T, Karakitsos D, Ledonne J, Doniger S, Scoppettuolo G, FellerKopman D, Schummer W, Biffi R, Desruennes E, Melniker LA, Verghese ST. International evidencebased recommendations on ultrasound-guided vascular access. Intensive Care Med. 2012; 38: 1105-17.

22- Chenkin J, McCartney CJ, Jelic T, Romano M, Heslop C, Bandiera G. Defining the learning curve of point-of-care ultrasound for confirming endotracheal tube placement by emergency physicians. Crit Ultrasound J. 2015; 7: 14

23- Liu ZL, Zhou T, Liang XB, Ma JJ, Zhang GJ. Learning curve of endorectal ultrasonography in preoperative staging of rectal carcinoma. Mol Clin Oncol. 2014; 2: 1085-1090.

24- Kim GH, Bang SJ, Hwang JH. Learning models for endoscopic ultrasonography in gastrointestinal endoscopy. World J Gastroenterol. 2015; 21: 517682 .

25- Jang T, Sineff S, Naunheim R, Aubin C. Residents should not independently perform focused abdominal sonography for trauma after 10 training examinations.J Ultrasound Med. 2004;23:793-7.

26- Jang T, Kryder G, Sineff S, Naunheim R, Aubin $\mathrm{C}$, Kaji AH. The technical errors of physicians learning to perform focused assessment with 
sonography in trauma. Acad Emerg Med. 2012; 19 : 98-101.

27- Tatar IG, Kurt A, Yilmaz KB, Akinci M, Kulacoglu $\mathrm{H}$, Hekimoglu B. The learning curve of real time elastosonography: a preliminary study conducted for the assessment of malignancy risk in thyroid nodules.Med Ultrason. 2013;15:278-84. 